
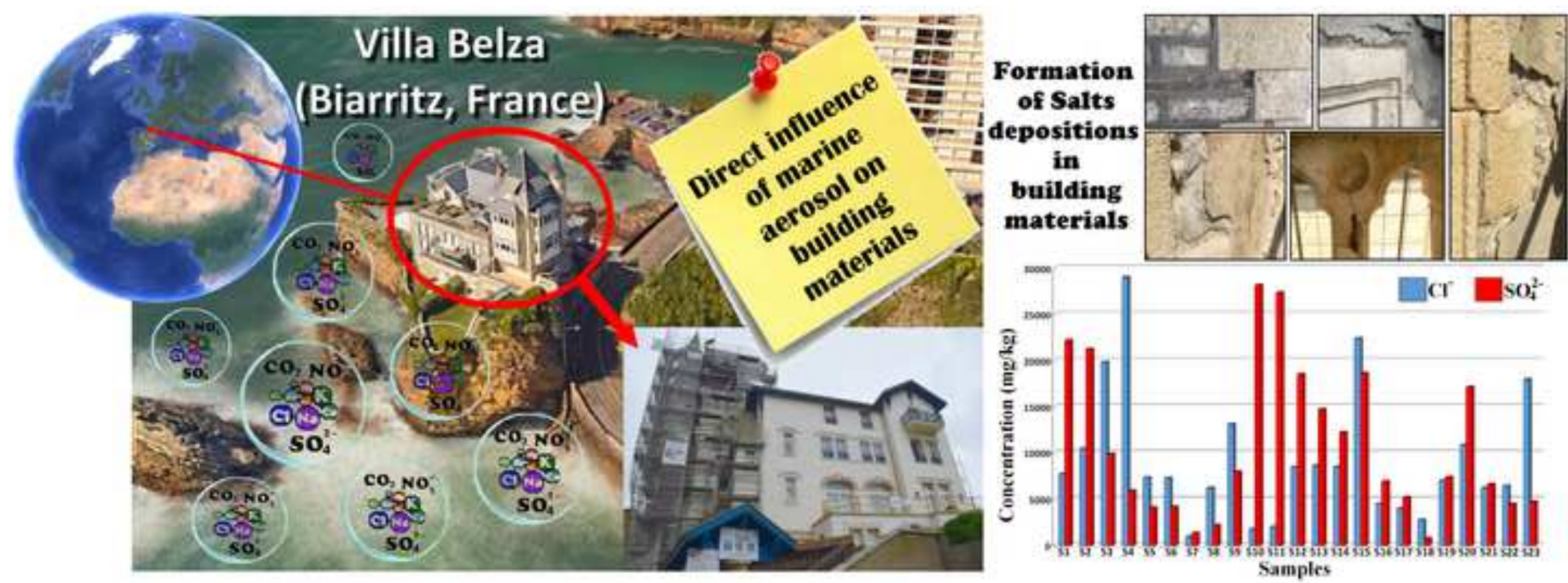


\section{HIGHLIGHTS}

- Nature and distribution of salts crystallizations in building materials of a construction close to the sea has been studied.

- XRD and Raman microscopy allowed to define the wide variety of sulfates presence.

- To define the chlorine presence EDXRF imaging should be implemented in the methodology.

- In some of the building materials both sulfates and chlorides concentration are close to $3 \% \mathrm{w} / \mathrm{w}$. 


\title{
Decay processes in buildings close to the sea induced by marine aerosol: Salt depositions inside construction materials
}

\author{
$\underline{\text { Héctor Morillas }}^{1,2}$, Fernando França de Mendonça Filho ${ }^{3 *}$, Hannelore Derluyn ${ }^{3}$, \\ Maite Maguregui $^{4}$, David Gregoire ${ }^{3,5}$, Juan Manuel Madariaga ${ }^{1}$ \\ ${ }^{1}$ Department of Analytical Chemistry, Faculty of Science and Technology, University of the Basque Country \\ UPV/EHU, P.O. Box 644, 48080 Bilbao, Basque Country, Spain \\ ${ }^{2}$ Department of Mathematics and Experimental Sciences Didactics, Faculty of Education, Philosophy and \\ Anthropology, University of the Basque Country UPV/EHU, II Building, Oñati Plaza 3, 20018 Donostia-San \\ Sebastian, Basque Country, Spain e-mail: hector.morillas@ehu.es \\ ${ }^{3}$ Universite de Pau et des Pays de l'Adour, E2S UPPA, CNRS, Total, LFCR, Anglet-Pau, France \\ ${ }^{4}$ Department of Analytical Chemistry, Faculty of Pharmacy, University of the Basque Country UPV/EHU, P.O. Box \\ 450, 01080 Vitoria-Gasteiz, Basque Country, Spain \\ ${ }^{5}$ Institut Universitaire de France \\ * currently at: Department of Materials, Mechanics, Management and Design, Faculty of Civil Engineering and \\ Geosciences, Delft University of Technology, P.O. Box 5048, 2600 GA, Delft, Netherlands
}

\section{Abstract}

Buildings close to the sea experience different kinds of decay processes related with the influence of marine aerosol. This sea spray is a chemically complex system formed by inorganic salts (sulfates, nitrates and mainly chlorides) and organic matter, together even with airborne particulate matter from the surrounding environment. Buildings close to the sea, erected using different materials such as bricks, plasters, limestones and sandstones, can experience many kinds of chemical reactions promoted by the impact of this sea spray, which favour the formation of salt crystallizations. In this work, a study of salts crystallizing in different kinds of building materials of a construction close to the Bay of Biscay (Villa Belza, Biarritz, France) has been studied in order to evaluate the state of conservation of the materials under study. The construction materials affected by salts were analysed by means of X-ray Diffraction (XRD) and $\mu$-Raman spectroscopy $(\mu-\mathrm{RS})$ for molecular analyses, Energy dispersive X-ray Fluorescence spectrometry ( $\mu$-ED-XRF) for elemental analyses and soluble salts tests by means of ion chromatography. These analyses revealed different levels of chlorides, nitrates and sulfates. Moreover, using this methodology, some specific chemical reactions that take place in the Villa Belza were understood. This knowledge can help to lay the foundations for possible future restoration works.

Keywords: marine aerosol, limestone, sandstone, XRD, ED-XRF, Ion Chromatography. 


\section{Introduction}

Buildings erected close to the sea can experience more chemical decay processes than others. These decay processes are usually alterations derived from physical or chemical interaction between building materials and the surrounding environment. This negative influence is closely related with marine aerosol. Marine aerosol is a chemical complex system formed by inorganic salts (Morillas et al. 2016a; 2018a) and organic matter (Bao et al., 2018; Miyazaki et al., 2018), together with airborne particulate matter (Calparsoro et al., 2017). The primary particles transported in the marine aerosol (PMA) can induce different chemical reactions in the atmosphere (Ceburnis et al., 2016; Xiao et al., 2018), promoting the so-called Secondary Marine Aerosol (SMA) particles (O'Dowd and de Leeuw, 2007). These kinds of particles, together with the natural crustal or mineral particles and the metallic airborne particulate matter emitted by anthropogenic sources (road traffic, industry, etc.) can be deposited on building materials from a specific construction following dry deposition processes (Morillas et al., 2016a). The interactions of these natural and anthropogenic stressors with building materials can promote different kinds of pathologies.

One of the most aggressive deterioration pathways promoted by marine aerosol is salt crystallization (Vallet et al., 2006) and thus the presence of soluble salts in the building materials used to erect construction. The damages caused by soluble salts in the building materials can be produced as result by several mechanisms based on the kind of crystallization (Granneman et al., 2019; Derluyn et al., 2014; Celik and Aygun, 2018).

The formation of these salts is not only an aesthetical problem when they become visible as efflorescences (Kamh et al., 2017). The main problem resides when salts precipitate beneath the material as subflorescences (Morillas et al., 2015). Indeed, its formation during time can get to crack materials and cause irreparable loss of material in the building. In this way, the level of damage by marine aerosol can vary depending on the characteristics of the material, such as limestone (Derluyn et al., 2013; 2019), sandstone (Raneri et al., 2015), bricks (Morillas et al., 2018b) and plaster (Morillas et al., 2013). 
The crystallization process occurs when the salt solubility is being exceeded, the salt solubility itself being temperature dependent (Onasch et al., 2000; Gomez-Heras and Fort, 2007; Zhang et al., 2014). When occurring in a building material, the pore size (Cultrone and Sebastian, 2008), water absorption capacity (Yang and Wang, 2019), mechanical strength (Chunran and Shicong, 2019) and pore size distribution (Molina et al., 2011) of the material play their role as well in salt-induced decay. The deposition and the crystal solubilization, and subsequently the entry of these soluble salts into the building material promotes the crystal growing in pores, or subsequent crystallizations in existing fissures, which gives rise to tensions promoting the enlargement of these areas (Ruedrich et al., 2007; Thiebaut et al., 2018). Under confined conditions, i.e. within the pores of the building material or within an existing fissure, the crystallization exerts a certain stress on the pore or fissure wall (Espinosa et al., 2008a), proportional to the natural logarithm of the supersaturation degree (Espinosa et al., 2008b). If this physical stress exceeds the tensile strength of the material, deterioration occurs.

For all these reasons, analytical monitoring of building materials as well as conservation interventions are strongly recommended in any process of decision-making related to the soluble salts presence (Mendonça Filho et al., 2019; Morillas et al., 2016b), with crystallization-induced decay one of the most aggressive deterioration processes affecting buildings erected in coastal areas.

In this work, a multianalytical methodology based on the combination of X-ray Diffraction (XRD) and $\mu$-Raman spectroscopy ( $\mu$-RS) for molecular analyses, Energy dispersive X-ray Fluorescence spectrometry (ED-XRF) for elemental analyses and soluble salts tests by means of ion chromatography was applied to the characterization of building materials used for the construction of the Villa Belza (Biarritz, France) and affected by the action of marine aerosol action.

\section{Materials and methods}

\subsection{Location and Sampling}

This study has been carried out on the façades from a building called the Villa Belza, which was built from 1880 until 1895. The construction is located at the coast of Biarritz, France, with direct exposition to sea spray (see Figure S1 from Supplementary Material and Table 1). The study has been performed in the façade opposite to the 
106 orientation of the sea, since it was not possible to extract samples from the opposite

107 façade oriented directly to the sea. 23 samples of different kinds of materials

108 (limestones, sandstone, cement and joint and rendering mortars) were collected at

109 different heights (see Figure 1) in order to observe possible differences in the

110 deterioration processes of building materials along the façade.

\section{2.2. Instrumentation}

112 For the molecular characterization of the 23 samples analyzed, XRD analyses were

113 carried out using a powder diffractometer PANalytical Xpert PRO instrument equipped 114 with a copper tube $(\lambda \mathrm{CuK} \alpha 1=1.54060 \AA, \lambda \mathrm{CuK} \alpha 2=1.54439 \AA)$, a vertical goniometer

115 (Bragg-Brentano geometry), a programmable divergence aperture, an automatic 116 interchange of samples, a secondary monochromator of graphite and a PixCel detector.

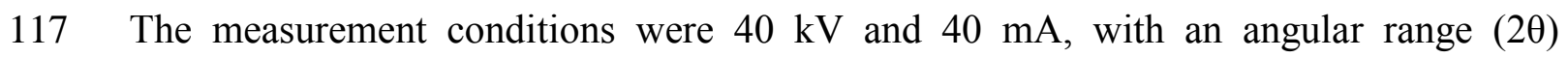

118 scanned between 5 and $70^{\circ}$. Moreover, X pert HighScore (PANalytical) software in

119 combination with the specific powder diffraction file database (International Centre for

120 Diffraction Data - ICDD, Pennsylvania, USA) was used for the data treatment of the

121 diffractograms and the identification of the present mineral phases.

122 In order to obtain complementary molecular information present in the Villa Belza 123 samples, Raman spectroscopy was used. For the micro-Raman analyses, the inVia 124 Renishaw confocal Raman microspectrometer (Renishaw, Gloucestershire, UK) 125 coupled to a DMLM Leica microscope with $5 \times, 20 \times$ and $50 \times$ long working distance 126 lens was used. A $514 \mathrm{~nm}$ excitation laser (with nominal laser power at $50 \mathrm{~mW}$ ) was 127 used. The spectrometer was daily calibrated by using the $520.5 \mathrm{~cm}^{-1}$ Raman band of a 128 silicon chip. Lasers were set at low power (not more than $1 \mathrm{~mW}$ at the sample) to avoid 129 sample decomposition. Data acquisition was carried out using the Wire 4.2 software 130 package (Renishaw). Spectra were acquired in the spectral region between 100 and $1313000 \mathrm{~cm}^{-1}$. Measurements were acquired between 5-30 s and several scans (between 1013240 scans) were accumulated for each spectrum to improve the signal-to-noise ratio. To 133 interpret all the Raman results, the acquired Raman spectra were compared with Raman 134 spectra of pure standard compounds collected in the e-VISNICH dispersive Raman 135 database (Maguregui et al., 2010) and with free Raman databases (e.g. RRUFF 136 (Downs and Hall-Wallace, 2002)) for the assignation of Raman bands. For the spectral 137 treatment and analysis, Wire 2.0 (Renishaw, Gloucestershire, UK) and OMNIC® 7.2 
138 software (Thermo Nicolet, Madison, WI, USA) were used. Once the compounds were 139 identified, they were classified as original or deterioration compounds. A given 140 compound is said to be identified if it appeared at least five times in different spectra 141 from the same sample.

142 For the elemental analysis of the samples, the M4 TORNADO (Bruker Nano GmbH, 143 Berlin, Germany) energy dispersive X-Ray fluorescence spectrometer (EDXRF) was 144 used. Measurements were conducted directly in the rock fragments using poly-capillary 145 lens, which are able to achieve a lateral resolution down to $25 \mu \mathrm{m}$ (measured at the Mo $146 \mathrm{~K} \alpha$ line). The $\mathrm{X}$-ray $\mathrm{Rh}$ anode tube implemented operates at up to $50 \mathrm{kV}$ with a 147 maximum current of $600 \mu \mathrm{A}$, which were the conditions considered for the spectral 148 acquisition. The detection of the fluorescence radiation was performed by an XFlash® 149 silicon drift detector with $30 \mathrm{~mm}^{2}$ sensitive area and energy resolution of $145 \mathrm{eV}$ for $150 \mathrm{Mn}-\mathrm{K} \alpha$. In order to improve the detection of the lightest elements $(Z<19)$, filters were 151 not used and measurements were acquired under vacuum (20 mbar). To achieve the 152 vacuum, a diaphragm pump MV 10 N VARIO-B (Vaccubrand, Wertheim, Germany) 153 was used. The live time used for each punctual measurement was 200 seconds. The spectral data acquisition and treatment was performed using the M4 TORNADO software (Bruker Nano GmbH, Berlin, Germany).

156 To determine the nature of the main colonizers in the greenish patina visible in some samples (e.g., S8 sample in Figure 1) from Villa Belza, Phase Contrast microscope 158 (PCM) was used. Micro-photographs of the colonized samples were obtained with a 159 Nikon DN100 camera coupled to a Nikon SMZ800 stereoscopic microscope and 160 microphotographs were captured with a Nikon DS Fi1 DS-Fi1 digital microscope 161 camera on a Nikon Eclipse 80 i PCM provided with $20 \times, 40 \times, 60 \times$ and $100 \times$ objective 162 lenses.

163 The quantification of soluble salts, present in the samples of the limestone, sandstone, 164 cement and joint and rendering mortars from Villa Belza, was conducted by ion 165 chromatography with conductivity detection after post-column ion suppression. Prior to 166 the soluble salt quantification, an extraction of the soluble cations and anions was 167 carried out using an ultrasound-based extraction method. All the samples were 168 homogenized in an agate mortar and dried in an oven at $75^{\circ} \mathrm{C}$ until constant weight. 169 After that, powdered and dried samples were subjected to an ultrasound extraction 
170 procedure in an ultrasound bath. $100 \mathrm{mg}$ of powdered sample with $100 \mathrm{ml}$ of Milli-Q 171 quality water (Millipore, USA) was placed in an ultrasound bath during $100 \mathrm{~min}$ in 172 order to extract soluble salts (anions and cations) from samples. Cations $\left(\mathrm{Ca}^{2+}, \mathrm{K}^{+}, \mathrm{Na}^{+}\right.$, $\left.173 \mathrm{Mg}^{2+}, \mathrm{NH}_{4}^{+}\right)$and anions $\left(\mathrm{Cl}^{-}, \mathrm{NO}_{3}^{-}, \mathrm{SO}_{4}{ }^{2-}\right)$ were quantified by means of ion

174 chromatography. For cations a Dionex UCS-5000 ion chromatograph and for anions a 175 Dionex ICS-2500 ion chromatograph connected to a conductimetric detector (ED50 176 Dionex conductimetric detector) with post-column suppression (Thermo Scientific ${ }^{\mathrm{TM}}$ 177 Dionex CERS 500, Dionex Corporation, Sunnyvaley, California, USA) was employed. 178 The experimental conditions used for the quantification of these anions are described 179 elsewhere (Prieto-Taboada et al. 2012).

\section{Results and discussion}

\subsection{Molecular analyses of the construction materials}

182 To determine the mineralogical composition of the construction materials of Villa

183 Belza, XRD analyses were carried out. In Table 1, a summary of the semi-quantitative 184 estimation of the minerals present in the analyzed samples in weight percentage (wt \%) 185 is presented. This estimation is based on the intensity (height) of the most intense peak 186 or diffraction maximum of each phase, and on the RIR (Reference Intensity Ratio) value 187 contained in the Powder Diffraction Files (PDF) referenced to the database (Zhou et al., 188 2018). The estimation is based on a single peak for each phase, mainly free of 189 interference with peaks of other phases. In some cases, their relative intensity might be 190 affected in the case of phases with preferential orientation. The RIR values are 191 fundamentally empirical and may vary somewhat between different PDF files of the 192 same mineral. In this calculation, only the identified phases are taken into consideration 193 for the semi-quantitative estimation, reaching the $100 \%$. In this sense, the unidentified 194 phases and the amorphous (non-crystalline) material that the samples could contain are 195 not considered. These estimations may be useful as a first approach, especially for 196 comparison among samples.

197 As can be seen in the Table 1, the principal mineralogical phases present in almost all 198 the samples were calcite $\left(\mathrm{CaCO}_{3}\right)$ and quartz $\left(\alpha-\mathrm{SiO}_{2}\right)$ contributing with different 199 percentages according to the type of material. Moreover, gypsum $\left(\mathrm{CaSO}_{4} \cdot 2 \mathrm{H}_{2} \mathrm{O}\right)$ and 
200 halite $(\mathrm{NaCl})$ are also present with variation in their percentages $(2-7 \%$ and $1-2 \%$ 201 respectively).

202 The highest content of gypsum was detected in S20 sandstone sample and samples S3,

203 S4 and S23 (rendering mortars). In these last rendering mortars, the highest concentrations $(2 \%)$ of halite $(\mathrm{NaCl})$ was also detected. Both, sulfates and chlorides, are closely related with the influence of marine aerosol. On the one hand, sulfates present in the sea spray, together with the $\mathrm{H}_{2} \mathrm{CO}_{3}$ aerosol, can react with the carbonaceous materials giving rise to the subsequent calcium sulfates. In this way, calcium carbonate is a highly soluble carbonate that can be dissolved due to the action of $\mathrm{CO}_{2}$ dissolved in atmospheric aerosols (see reaction 1) and therefore the solubilized $\mathrm{Ca}^{2+}$ can react with the $\mathrm{SO}_{4}{ }^{2-}$ coming from sea spray (see reactions 2) giving rise to gypsum formation after

211 a previous formation of anhydrite $\left(\mathrm{CaSO}_{4}\right)$.

$212 \mathrm{CaCO}_{3}(\mathrm{~s})+\mathrm{H}_{2} \mathrm{CO}_{3}(\mathrm{dis}) \leftrightarrows \mathrm{Ca}^{2+}+2 \mathrm{HCO}_{3}^{-}$

$\mathrm{Ca}^{2+}+\mathrm{SO}_{4}^{2-} \leftrightarrows \mathrm{CaSO}_{4}($ dis $) \leftrightarrows \mathrm{CaSO}_{4} \cdot 2 \mathrm{H}_{2} \mathrm{O}(\mathrm{s})$

214 On the other hand, the halite present in the sample at concentrations between $1-2 \%$ can 215 be present in the building materials coming from the dry deposition of marine aerosol. 216 Chlorides can migrate to the inner areas and re-crystallize, promoting $\mathrm{NaCl}$ 217 subflorescence, which under natural radiation can produce partial disruption of the 218 porous surface, producing micro-spallings (Gómez-Heras and Fort, 2007). This kind 219 of pathology is visible in Villa Belza contruction.

220 In samples S4 (rendering mortar) and S15 (joint mortar) apart from the mentioned 221 compounds, additional specific decay compounds were also detected (see Figure 2). In 222 Figure S4, apart from calcite and quartz (matrix composition), halite and portlandite 223 were also detected (see Figure 2A). As explained above, halite presence is related to the 224 marine influence, but portlandite $\left(\mathrm{Ca}(\mathrm{OH})_{2}\right)$ presence cannot be connected to this stressor source. Portland cement can suffer different decay processes. The cement typically provides to a building construction an alkaline protection with a $\mathrm{pH}$ around 12 .

227 Nevertheless, sometimes, due to the surrounding environment, this $\mathrm{pH}$ can decrease to 22810 losing its inherent protection. Consequence of it is the carbonation of the cement 229 (reaction between atmospheric $\mathrm{CO}_{2}$ and the $\mathrm{Ca}(\mathrm{OH})_{2}$, which can be catalyzed by 230 chlorides and sulfates from marine aerosol (Broomfield, 2006). 
231 In sample S15, apart from calcite and quartz, pyroaurite $\left(\mathrm{Mg}_{6} \mathrm{Fe}_{2}\left(\mathrm{CO}_{3}\right)(\mathrm{OH})_{16} \cdot 4 \mathrm{H}_{2} \mathrm{O}\right)$ 232 and ettringite $\left(\mathrm{Ca}_{6} \mathrm{Al}_{2}\left(\mathrm{SO}_{4}\right)_{3}(\mathrm{OH})_{12} \cdot 26 \mathrm{H}_{2} \mathrm{O}\right)$ were also detected (see Figure $2 \mathrm{~B}$ ). As it is 233 known, for the preparation of mortars, sand, water and a binder (hydraulic and non234 hydraulic lime or cement) are used. This cement is obtained by calcination of calcite 235 and clay that later is milled producing the clinker (composed by different lime silicates) 236 (Elsen, 2006). Subsequently, the cement included in the constructions can suffer the 237 influence of marine aerosol. The material reacts with the chlorides and sulfates mainly 238 present in the aerosol, leading to chemical reactions inside the cement pores (García239 Florentino et al., 2016). An example of it is the formation of ettringite 240 (Apostolopoulou et al., 2018), which can lead to expansive reactions leading to 241 material cracking. Regarding pyroaurite $\left(\mathrm{Mg}_{6} \mathrm{Fe}_{2}\left(\mathrm{CO}_{3}\right)(\mathrm{OH})_{16} \cdot 4 \mathrm{H}_{2} \mathrm{O}\right)$, there are works 242 that previously described its formation in laboratory controlled conditions. For the 243 formation of this compound, $\mathrm{FeCO}_{3}$ and $\mathrm{Mg}$-rich environment with oxidation processes 244 at a $\mathrm{pH}$ of 8.5 is necessary (Hansen and Taylor, 1990).

245 Additionally, in sample S13 (sandstone) a greenish color was observed. In this sample, 246 the main component was quartz $\left(95 \%\right.$ of $\left.\alpha-\mathrm{SiO}_{2}\right)$, calcite $\left(2 \%\right.$ of $\left.\mathrm{CaCO}_{3}\right)$, gypsum $(2 \%$ 247 of $\left.\mathrm{CaSO}_{4} \cdot 2 \mathrm{H}_{2} \mathrm{O}\right)$ and halite $(1 \%$ of $\mathrm{NaCl})$. The XRD diffractogram of sample $\mathrm{S} 13$ 248 showed an elevation of the spectral background that suggested the existence of 249 amorphous phases (organic or non-crystalline). Considering that the greenish patina in 250 the sample can be related with a biocolonization (see Figure S2 from Supplementary 251 Material), the sample was investigated by means of Phase Contrast Microscopy (PCM). 252 Thanks to the microscopic observations, many cyanobacteria colonies were identified. 253 As it can be seen in Figure S3A and S3B from Supplementary Material, different 254 characteristics of coccoid cells and cyanobacterial cells in division even showing their 255 pseudo-filaments were observed. Finally, cyanobacterial cells with their endospores or 256 baeocytes were also observed (see Figure S3C and S3D from Supplementary Material).

257 These microscopic observations-suggest that the greenish color is connected to the 258 cyanobacteria colonies; more specifically the Pleurocapsales order and the gender 259 Pleurocapsa. This kind of cyanobacteria typically colonize high content quartz 260 limestones (Shalygin et al., 2019).

261 In the sample S20, the main mineralogical phases were quartz (80\%), calcite (12\%), 262 gypsum (7\%) and halite (1\%). The semi-quantitative content of calcite is relatively low 263 (12\%), but taking into account the high content of gypsum (7\%), it is clear that a 
sulfation process is taking place in this area. The calcite present in this sandstone sample can be transformed into gypsum through a sulfation process promoted by the load of sulfates present in the marine aerosol (Zezza and Macri, 1995). These reactions have been described previously (see reactions 1-2).

268 Additionally, Raman microscopy was performed to complement the molecular information obtained by XRD. Owing to the fact that using XRD it is not possible to determine amorphous mineral phases or minor compounds (below $1 \%$ in weight), Raman microscopy was used to complement the possible detection of additional compounds at minor or trace levels. For this reason, apart from the same mineralogical phases observed by XRD, additional ones were also detected by Raman spectroscopy. In many samples, aluminosilicates such as adularia $\left(\mathrm{KAlSi}_{3} \mathrm{O}_{8}\right)$; quartz $\left(\mathrm{SiO}_{2}\right)$; rutile $\left(\mathrm{TiO}_{2}\right)$; calcite $\left(\mathrm{CaCO}_{3}\right)$ and charcoal $(\mathrm{C})$ were also identified

In most of the studied samples (S1, S2, S9, S10, S11, S12, S13, S14 and S20) different kind of calcium sulfates were detected (see Figure 3), such as gypsum (main Raman 278 bands at 414, 493, 616, 670, 1008 and $1132 \mathrm{~cm}^{-1}$ ) (see Figure 3A), bassanite $279\left(\mathrm{CaSO}_{4} \cdot 1 / 2 \mathrm{H}_{2} \mathrm{O}\right.$, main Raman bands at 430, 488, 627, 668 and $\left.1015 \mathrm{~cm}^{-1}\right)$ (see Figure 280 3B) and anhydrite $\left(\mathrm{CaSO}_{4}\right.$, main Raman bands at 422, 492, 631, 673, 1024 and 1166 $\mathrm{cm}^{-1}$ ) (see Figure 3C). In this last case, the additional band at $1086 \mathrm{~cm}^{-1}$ that belongs to calcite (see Figure 3C) was also registered. The identification of calcium sulfate crystallization with different hydration waters is related with the dehydration process of the gypsum previously formed in the different building materials (sandstone, limestone and joint and rendering mortar) from Villa Belza construction. These transformations start when water evaporation processes take place under some specific reactions described elsewhere (Morillas et al., 2013). Hydration and dehydration cycles promote an increase and decrease in the size of the crystals formed in the pores of the building materials, which can lead to possible cracks and loss of material.

\subsection{Elemental analysis of the construction materials}

291 In addition to the molecular measurements, $\mu$-EDXRF imaging analysis was also

292 performed to extract additional conclusions about the conservation state of the materials used in the Villa Belza construction. First, different single point EDXRF spectra (down to $25 \mu \mathrm{m}$ of lateral resolution) were acquired to identify the elements of interest. After that, different mappings were performed. In Figure 4, an example of the elemental 
distribution maps obtained in sample S15 (joint mortar) is displayed. Although some

297 elements such as $\mathrm{Pb}, \mathrm{As}, \mathrm{Fe}, \mathrm{Co}$ and $\mathrm{Cu}$ are quite homogeneously distributed in the mapped area (see Figure 4A to D), specific hotspots of these elements which show a higher intensity of their respective $\mathrm{K}_{\alpha}$ lines (except for $\mathrm{Pb}$, which $\mathrm{L}_{\alpha}$ line was used for

300 data interpretation) are also observable. Elements such as Ti-V-Cr (see Fig 4E) are

301 heterogeneously distributed in the sample.

302 Moreover, in the whole section of the joint mortar, aluminosilicates are widely 303 distributed (see K-Al-Si distribution in Figure 4F), probably as adularia or microcline according to XRD and Raman results. In the Figure 4G the clear distribution of the aggregate $(\mathrm{Si})$ and the binder $(\mathrm{Ca})$ is observable. The white central vein in the mapped area is connected not only to $\mathrm{Ca}$, but also to $\mathrm{Mg}$ (see Figure $4 \mathrm{~F}$ and $\mathrm{H}$ ), which can suggest a mixed presence of calcite and dolomite, the presence of Mg-rich calcite or even dolomite $\left(\mathrm{CaMg}\left(\mathrm{CO}_{3}\right)_{2}\right)$. This last carbonate was identified in some of the samples considered in this work (see Table 1). The non-detection of it in sample S15 does not imply that this carbonate is not present, because it can be set under the detection limit of the applied XRD methodology.

312 It is also remarkable that in samples $\mathrm{S} 15, \mathrm{Zn}$ is specifically accumulated in a concrete 313 position in the mapped area (see Figure 4F). In some areas of the analyzed sample, the

314 distribution of $\mathrm{Ca}$ and $\mathrm{S}$ is coincident (see pink-purple areas in Figure $4 \mathrm{H}$ ), suggesting 315 the possible presence of calcium sulfates (gypsum, anhydrite or basanite) in the inner 316 part of the joint mortar. Calcium sulfates were not identified in this sample by XRD 317 probably because their concentration was set under the limit of detection of the 318 technique. In this sense, if an elemental study had not been accomplished, the 319 identification of sulfates at low concentrations in the sample would not have been 320 carried out.

321 Apart from sulfates, the high correlation between $\mathrm{Na}$ and $\mathrm{Cl}$ distribution maps (see 322 Figure 4I) suggests the crystallization of $\mathrm{NaCl}$ inside the $\mathrm{S} 15$ joint mortar. Once more, 323 this halide was not detected by XRD. Halite crystallizations can promote many physical 324 problems in the building material structures promoting cracks and loss of material. 325 Additionally, $\mathrm{Cl}-\mathrm{Mg}$ showed coincident distributions (greenish yellow in the Figure 4J) 326 in the corners of the central vein, both elements present in the marine aerosol. 
327 Different elemental mappings obtained from S17 and S7 samples respectively are also 328 presented in the Figures S4 and S5 from the Supplementary Material. Regarding the original components in the samples (calcite and aluminosilicates mainly), the conclusions that can be extracted are quite similar to those obtained for sample S15.

331 On the one hand, in sample S17, the areas showing a coincident distribution of $\mathrm{Ca}$ and S

332 (see Figure S4 from Supplementary Material) are lower than the ones detected in S15, 333 which suggest a lower presence of calcium sulfates. Once again, the white vein detected 334 in this sample also shows a high correlation between $\mathrm{Ca}$ and $\mathrm{Mg}$, being possible to 335 extract the same conclusion previously introduced. In this sample, it is clearly evident 336 that $\mathrm{NaCl}$ is widely distributed (see Figure S4 from Supplementary Material), 337 suggesting a high impact of marine aerosol in the mentioned sample. On the other hand, 338 sample S7 belongs to a section of a limestone from the construction. In it, the punctual 339 presence of silicates and some aluminosilicates are also observable (see Figure S5 from

340 Supplementary Material). In some specific areas where aluminosilicates are present, the 341 intensity of the $\mathrm{Fe}, \mathrm{Ti}, \mathrm{V}$ and $\mathrm{Cr} \mathrm{K}_{\alpha}$ line is also higher, suggesting a possible 342 contribution of these metals in the aluminosilicates. In this sample also, although the 343 intensity of the $\mathrm{Ca}$ line is much higher than the one of $\mathrm{S}$, both elements showed a 344 coincident distribution (purple areas in Figure S5 from Supplementary Material), which 345 suggest a possible sulfation of the limestome. In this case, also, the presence of $\mathrm{NaCl}$ 346 crystallizations are also visible due to the coincident distribution of $\mathrm{Na}$ and $\mathrm{Cl}$ (see 347 Figure S5 from Supplementary Material). As in the previous samples, in this case also it 348 was not possible to detect the presence of calcium sulfates and halite in the XRD 349 diffractograms, suggesting that both kind of salts crystallizations could be set at 350 concentrations lower than $1 \%$. Additionally, many different potassium and iron 351 alumino silicates, mica $\left(\mathrm{AC}_{2-3} \mathrm{~T}_{4} \mathrm{O}_{10} \mathrm{X}_{2}\right)$ and possible kaolinite $\left(\mathrm{Al}_{2} \mathrm{Si}_{2} \mathrm{O}_{5}(\mathrm{OH})_{4}\right)$ were 352 also observed in S7 as component of the limestones used for Villa Belza construction 353 (see Figure S5 from Supplementary Material). Moreover, others elements such as Co 354 and $\mathrm{Mn}-\mathrm{Fe}$ are also quite homogeneous distributed and elements such as Ti-Cr-V, 355 heterogeneous distributed in the limestone matrix.

\section{3.3. Quantification of soluble salts}

The results obtained from the elemental and molecular spectroscopic analyses suggest that all the building materials used for the Villa Belza construction are affected by the 
crystallization of mainly sulfate and chloride salts. To confirm the magnitude of this

360 impact, soluble salts were extracted and quantified to determine their specific nature.

361 The concentrations of the anions and cations obtained after the soluble salts test are presented in Figure 5 (see also Table S1 in Supplementary Material). The results are expressed as the average concentration of each ion together with the relative standard deviation (at 95\% confidence interval) calculated from three sample portions (subsamples) for each sample.

366 Regarding the quantified ions, the twenty-three building material samples showed the presence of $\mathrm{Li}^{+}$and $\mathrm{NH}_{4}{ }^{+}$at low concentrations. Lithium is one of the most common cations present in marine aerosol (Weller et al., 2008). Although the presence of ammonium in sea spray as ammonium nitrate $\left(\mathrm{NH}_{4} \mathrm{NO}_{3}\right)$ and ammonium sulfate $\left(\left(\mathrm{NH}_{4}\right)_{2} \mathrm{SO}_{4}\right)$ (Guth et al., 2018; Park et al., 2018) is widely known, the concentrations determined in all the samples are quite low (average of $28 \mathrm{mg} / \mathrm{kg}$ approximately). This could be related with the high solubility of ammonia. The concentration of $\mathrm{NH}_{4}{ }^{+}$in other works related with buildings close to the sea at the Atlantic coast was similarly low (under limit of detection or even non-detected) (García-Florentino et al., 2016).

Regarding alkali and alkaline earth cations, the concentrations in general terms are higher for $\mathrm{Mg}^{2+}$ than for $\mathrm{K}^{+}$(506 vs $485 \mathrm{mg} / \mathrm{kg}$ respectively). On the one hand, the samples that contain more than $600 \mathrm{mg} / \mathrm{kg}$ of $\mathrm{K}^{+}$are S3, S4, S20 and S23. Moreover, these three samples have a similar calcite proportion (around $50 \%$ ). Calcite is a very soluble compound, in the continuous contact with the $\mathrm{H}_{2} \mathrm{CO}_{3}$ aerosol, which can react after solubilization with other anions and cations coming from the sea spray giving rise to different $\mathrm{K}^{+}$compounds (Morillas et al., 2013). On the other hand, as can be seen in the bar chart of Figure 5, the samples that show the highest concentrations of $\mathrm{Mg}^{2+}$ are S9, S12, S13, S14, S17 and S19 samples. For the unique only sandstone sample (S9) analyzed in this work, $8 \%$ (wt \%) of dolomite was detected (see Table 1), thus the high $\mathrm{Mg}^{2+}$ concentration could be related with the presence of this carbonate. On the contrary, in the rest of the samples where high concentrations of $\mathrm{Mg}^{2+}$ were determined, dolomite was not identified. The high presence of this cation could be related with the presence of salts including this alkaline earth cation such as epsomite $\left(\mathrm{MgSO}_{4} \cdot 7 \mathrm{H}_{2} \mathrm{O}\right)$. Although this compound was not observed, neither by means of XRD nor by means of Raman spectroscopy, its presence cannot be discarded because this decay compound is very common to find in buildings close to the sea (López-Arce et al., 2009). 
392 The highest concentration of cations were registered for $\mathrm{Ca}^{2+}$ and $\mathrm{Na}^{+}$. Calcium was one

393 of the most concentrated elements (average concentration around $14236 \pm 4790 \mathrm{mg} / \mathrm{kg}$ ).

394 This matches with the XRD and Raman analyses where calcite and gypsum were 395 detected and this element is thus related with the presence of these compounds. In the 396 samples S4 (rendering mortar) and S15 (joint mortar), where the highest concentration

397 of $\mathrm{Ca}^{2+}$ was observed, decay compounds such as portlandite and ettringite were 398 detected. The presence of $\mathrm{Na}^{+}$(average concentration of $5068 \pm 3102 \mathrm{mg} / \mathrm{kg}$ ) in all the 399 samples is closely related with the halite $(\mathrm{NaCl})$ salts crystallizations detected in the 400 samples (Cardell et al., 2003). The concentration of $\mathrm{Na}^{+}$is the highest in samples $\mathrm{S} 3$, 401 S4 and S23 (11960, 10890 and $11330 \mathrm{mg} / \mathrm{kg}$ for S3, S4 and S23 respectively). This 402 observation matches with the XRD results (see Table 1), where besides that these three 403 samples have a similar calcite proportion (around $50 \%$ ), they have the highest 404 proportion of halite (2\%). In marine environments, for approximately every $5000 \mathrm{mg} / \mathrm{kg}$ 405 of $\mathrm{Na}^{+}$concentration, the construction material can be lost $1 \%$ (wt \%) (due to spalling) 406 and form halite in marine environments induced by marine aerosol.

407 Finally, the highest concentrations of anions are those of $\mathrm{Cl}^{-}$and $\mathrm{SO}_{4}{ }^{2-}$, with average 408 concentrations of $9254 \pm 7002$ and $10926 \pm 8328 \mathrm{mg} / \mathrm{kg}$ respectively. Samples S3, S4 409 and $\mathrm{S} 23$ show the highest $\mathrm{Cl}^{-}$and $\mathrm{Na}^{+}$concentration. This observation corroborates the 410 findings presented above in which the halite was detected clearly in the three cases. 411 Moreover, samples S1, S2, S10, S11, S12, S13, S15 and S20 hold the higher $\mathrm{SO}_{4}{ }^{2-}$ 412 concentrations. According to Table 1, all of these sulfate concentrations are related with 413 the presence of gypsum $\left(\mathrm{CaSO}_{4} \cdot 2 \mathrm{H}_{2} \mathrm{O}\right)$ in these samples except for the case of $\mathrm{S} 15$ for 414 which the sulfate is linked to the presence of ettringite $\left(\mathrm{Ca}_{6} \mathrm{Al}_{2}\left(\mathrm{SO}_{4}\right)_{3}(\mathrm{OH})_{12} \cdot 26 \mathrm{H}_{2} \mathrm{O}\right)$.

\section{4. Conclusions}

416 The multianalytical methodology based on the use of XRD and Raman spectroscopy for 417 molecular analyses and $\mu$-ED-XRF for elemental analyses, together with soluble salts 418 quantification by means of ion chromatography allowed to define the nature and 419 concentration of the salts which affect the conservation state of the building materials 420 (limestone, sandstone, rendering and joint mortars) used in a construction next to the 421 sea, the Villa Belza building.

422 Thanks to XRD and Raman spectroscopy, it was possible to identify different kind of 423 sulfate crystallizations in building materials, whose concentration was set around 0.08-3 
$424 \%$ depending the considered building material. The identification of gypsum, 425 dehydrated and hemihydrated calcium sulfates (anhydrite and basanite) suggests that 426 dehydration/hydration cycles are taking place in the materials, which promote a 427 volume/size change in the salt crystallized in their pores, which can be responsible for 428 crack formations and fissures in the building material.

429 Apart from sulfates, chlorines were also detected by XRD. Considering the limit of 430 detection of the technique (around 1\% (wt \%), it becomes mandatory to use additional 431 techniques to detect its presence. To perform a non-invasive study, $\mu$-EDXRF imaging 432 will be a good alternative, which allows to perform a screening of the samples to detect 433 the presence of chlorine salts crystallizations. In the Villa Belza building materials, $\mathrm{Na}$ and $\mathrm{Cl}$ maps showed a coincident distribution, confirming the presence of halite in the samples. Thanks to the soluble salts test, it was possible to asses that the concentration of chlorides was between 0.1 and $3 \%$.

437 According to the extracted results, it can be affirm that this methodology can be integrated as a routine tool to extract conclusions related to the conservation state of building materials. In this case, that the building materials of Villa Belza are notoriously

440 affected by the influence of marine aerosol, being the main cause of salts 441 crystallizations. Building materials affected by salts can be desalinated following 442 different procedures and methodologies (e.g., chemical and mechanical methods, use of 443 slaughter mortars, immersion baths, electrochemical methods, etc.). However, the 444 constant input of salts coming from marine aerosol will promote subsequent 445 crystallization in the materials. In this sense, for future restorations of the construction, 446 if the materials will be replaced, appropriate materials resistant to this influence should 447 be selected. Therefore, this methodology capable of determining the original 448 composition of the affected building material and the nature and content of the newly 449 formed salts can be useful for civil engineers, architects, restorers and other scientist 450 that aim to preserve building materials of constructions erected not only in a marine 451 environment, but also in other locations affected by different environmental stressors. 
454 The authors gratefully acknowledge the financial support from the Communauté 455 d'agglomération Pau Béarn Pyrénées, from the ED211 doctoral school and from the 456 project IT-742-13 for Consolidated Research Groups, funded by the Basque

457 Government. The authors are thankful to the TMH restoration company who granted the 458 access to the Villa Belza during its restoration. The authors also thank Professor Isabel 459 Salcedo (Department of Plant Biology and Ecology, University of the Basque Country).

460 D. Gregoire is fellow of the Institut Universitaire de France.

\section{References}

462 Bao, H., Niggemann, J., Luo, L., Dittmar, T., Kao, S-J., Molecular composition and 463 origin of water-soluble organic matter in marine aerosols in the Pacific off China. Atmos. Environ. 191 (2018) 27-35.

465

466

467

468

469

470

471

472

473

474

475

476

477

478

479

480

481

482

Broomfield, J.P., Corrosion of Steel in Concrete: Understanding, Investigation and Repair, Publisher: CRC Press, ed. Taylor \& Francis (London, UK), 2006.

Calparsoro, E., Maguregui, M., Giakoumaki, A., Morillas, H., Madariaga, J.M., Evaluation of black crust formation and soiling process on historical buildings from the Bilbao metropolitan area (north of Spain) using SEM-EDS and Raman microscopy. Environ. Sci. Pollut. Res. 24 (2017) 9468-9480.

Cardell, C., Delalieux, F., Roumpopoulos, K., Moropoulou, A., Auger, F., Van Grieken, R., Salt-induced decay in calcareous stone monuments and buildings in a marine environment in SW France, Construct. Build. Mater. 17(3) (2003) 165-179.

Ceburnis, D., Rinaldi, M., Ovadnevaite, J., Martucci, G., Giulianelli, L., O'Dowd, C. D., Marine submicron aerosol gradients, sources and sinks. Atmos. Chem. Phys. 16(19) (2016) 12425-12439.

Celik, M. Y., Aygun, A., The effect of salt crystallization on degradation of volcanic building stones by sodium sulfates and sodium chlorides, B. Eng. Geol. Environ. (2018) Ahead of Print.

Chunran, W., Shicong K, Effects of high-calcium sepiolite on the rheological behaviour and mechanical strength of cement pastes and mortars, Construct. Build. Mater. 196 (2019) 105-114. 
Cultrone, G., Sebastian, E., Laboratory simulation showing the influence of salt efflorescence on the weathering of composite building materials, Environ. Geol. 56(3-4) (2008) 729-740.

Derluyn, H., Griffa, M., Mannes, D., Jerjen, I., Dewanckele, J., Vontobel, P., Sheppard, A., Derome, D., Cnudde, V., Lehmann, E., Carmeliet, J., Characterizing saline uptake and salt distributions in porous limestone with neutron radiography and X-ray micro-tomography, J. Build. Phys. 36 (2013) 353-374.

Derluyn, H., Dewanckele, J., Boone, M. N., Cnudde, V., Derome, D., Carmeliet, J., Crystallization of hydrated and anhydrous salts in porous limestone resolved by synchrotron x-ray microtomography, Nucl. Instrum. Meth. B 324 (2014) 102112

Derluyn, H., Vontobel, P., Mannes, D., Derome, D., Lehmann, E., Carmeliet, J., Saline Water Evaporation and Crystallization-Induced Deformations in Building Stone: Insights from High-Resolution Neutron Radiography, Transport Porous Med. 128(3) (2019) 895-913.

Elsen, J., Microscopy of historic mortars—a review, Cem. Concr. Res. 36 (2006) 14161424.

Espinosa, R.M., Franke, L., Deckelmann, G., Model for the mechanical stress due to the salt crystallization in porous materials, Construct. Build. Mater. 22 (2008a) 1350-1367.

Espinosa, R.M., Franke, L., Deckelmann, G., Phase changes of salts in porous materials: Crystallization, hydration and deliquescence, Construct. Build. Mater. 22 (2008b) 1758-1773.

García-Florentino, C., Maguregui, M., Morillas, H., Balziskueta, U., Azcarate, A., Arana, G., Madariaga, J.M., Portable and Raman imaging usefulness to detect decaying on mortars from Punta Begoña Galleries (Getxo, North of Spain), J. Raman Spectrosc. 47 (2016) 1458-1466

Gómez-Heras, M., Fort, R., Patterns of halite $(\mathrm{NaCl})$ crystallisation in building stone conditioned by laboratory heating regimes, Environ. Geol. 52(2) (2007) 259267. 
513 Granneman, S. J. C., Lubelli, B., van Hees, R. P. J., Effect of mixed in crystallization modifiers on the resistance of lime mortar against $\mathrm{NaCl}$ and $\mathrm{Na}_{2} \mathrm{SO}_{4}$ crystallization. Construct. Build. Mater. 194 (2019) 62-70.

516 Guth, J., Marecal, V., Josse, B., Arteta, J., Hamer, P., Primary aerosol and secondary inorganic aerosol budget over the Mediterranean Basin during 2012 and 2013, Atmos. Chem. Phys., 18 (2018) 4911-4934.

Hansen, H.C.B., Taylor, R.M., Formation of synthetic analogues of double metalhidroxy carbonate minerals under controlled $\mathrm{pH}$ conditions: I. The synthesis of Pyroaurite and Reevesite, Clay Miner. 25 (1990) 161-179

Kamh, G. M. E., Koltuk, S., Ismael, H., Refinement of categorization and scaling of weathering-related damage to natural stone: case study on oolitic limestone from El-Shatbi Tombs (Egypt). B. Eng. Geol. Environ. 76(1) (2017) 39-57.

Lopez-Arce, P., Doehne, E., Greenshields, J., Benavente D., Young, D., Treatment of rising damp and salt decay: the historic masonry buildings of Adelaide, South

Mendonça Filho, F.F., Morillas, H., Derluyn, H., Maguregui, M., Gregoire, D., In-situ versus laboratory characterization of historical site in marine environment using X-ray fluorescence and Raman spectroscopy, Microchem. J. 147 (2019) 905-

Miyazaki, Y., Yamashita, Y., Kawana, K., Tachibana, E., Kagami, S., Mochida, M., Suzuki, K., Nishioka, J., Chemical transfer of dissolved organic matter from surface seawater to sea spray water-soluble organic aerosol in the marine atmosphere, Scientific Reports 8(1) (2018) 1-10.

Molina, E., Cultrone, G., Sebastián, E., Alonso, F. J., Carrizo, L., Gisbert, J., Buj, O., The pore system of sedimentary rocks as a key factor in the durability of

Morillas, H., Maguregui, M., Gomez-Laserna, O., Trebolazabala, J., Madariaga, J.M., Could marine aerosol contribute to deteriorate building materials from interior areas of lighthouses? An answer from the analytical chemistry point of view, J. Raman Spectrosc. 44 (2013) 1700-1710. 
Morillas, H., Maguregui, M., Trebolazabala, J., Madariaga, J.M., Nature and origin of white efflorescence on bricks, artificial stones, and joint mortars of modern houses evaluated by portable Raman spectroscopy and laboratory analyses, Spectrochim. Acta A 136 (2015) 1195-1203.

Morillas, H., Maguregui, M., García-Florentino, C., Marcaida, I., Madariaga, J.M., Study of particulate matter from Primary/Secondary Marine Aerosol and anthropogenic sources collected by a self-made passive sampler for the evaluation of the dry deposition impact on Built Heritage, Sci. Total Environ. 550 (2016a) 285-296.

Morillas, H., García-Galán, J., Maguregui, M., Marcaida, I., García-Florentino, C., Carrero, J.A., Madariaga, J.M., Assessment of marine and urban-industrial environments influence on built heritage sandstone using X-ray fluorescence spectroscopy and complementary techniques, Spectrochim. Acta B 123 (2016b) $76-88$.

Morillas, H., Marcaida, I., García-Florentino, C., Maguregui, M., Arana, G., Madariaga, J.M, Micro-Raman and SEM-EDS analyses to evaluate the nature of salt clusters present in secondary marine aerosol, Sci. Total. Environ. 615 (2018a) 691-697.

Morillas, H., Garcia-Florentino, C., Marcaida, I., Maguregui, M., Arana, G., Silva, L. F. O., Madariaga, J. M., In-situ analytical study of bricks exposed to marine environment using hand-held X-ray fluorescence spectrometry and related laboratory techniques, Spectrochim. Acta B 146 (2018b) 28-35.

O'Dowd, C.D., de Leeuw, G., Marine aerosol production: a review of the current knowledge. Phil. Trans. R. Soc. A 365 (2007) 1753-1774.

Onasch, T.B., McGraw, R., Imre, D., Temperature-Dependent Heterogeneous Efflorescence of Mixed Ammonium Sulfate/Calcium Carbonate Particles, J. Phys. Chem. A 104 (2000) 10797-10806.

Park, M., Joo, H.S., Lee, K., Jang, M., Kim, S.D., Kim, I., Borlaza, L.J.S., Lim, H., Shin, H., Chung, K.H., Choi, Y-H., Park, S.G., Bae, M-S., Lee, J., Song, H., Park, K., Differential toxicities of fine particulate matters from various sources, Scientific Reports 8(1) (2018) 1-11. 
Prieto-Taboada, N., Gómez-Laserna, O., Martínez-Arkarazo, I., Olazabal, M.A., Madariaga, J.M., Optimizations of two methods based on ultrasound energy as alternative to European standards from soluble salts extraction from building materials, J. Ultrasound Sonochem. 19(6) (2012) 1260-1265.

Raneri, S., Cnudde, V., De Kock, T., Derluyn, H., Barone, G., Mazzoleni, P., X-ray computed micro-tomography to study the porous structure and degradation processes of a building stone from Sabucina (Sicily), Eur. J. Mineral. 27(3) (2015) 279-288.

Rosina, E., Sansonetti, A., Erba, S., Focus on soluble salts transport phenomena: The study cases of Leonardo mural paintings at Sala delle Asse (Milan), Construct. Build. Mater. 136 (2017) 643-652.

Ruedrich, J., Seidel, M., Rothert, E., Siegesmund, S., Length changes of sandstones caused by salt crystallization, Geol. Soc. Spec. Publ. 271(1) (2007) 199-209.

Shalygin, S., Kavulic, K.J., Pietrasiak, N., Bohunicka, M., Vaccarino, M.A., Chesarino, N.M., Johansen, J.R., Neotypification of Pleurocapsa fuliginosa and epitypification of P. minor (Pleurocapsales): resolving a polyphyletic cyanobacterial genus, Phytotaxa 392(4) (2019) 245-263.

Thiebaut, Y., Multon, S., Sellier, A., Lacarrière, L., Boutillon, L., Belili, D., Linger, L., Cussigh, F., Hadji, S., Effects of stress on concrete expansion due to delayed ettringite formation, Construct. Build. Mater. 183 (2018) 626-641.

Vallet, J. M., Gosselin, C., Bromblet, P., Rolland, O., Verges-Belmin, V., Kloppmann, $\mathrm{W}$., Origin of salts in stone monument degradation using sulphur and oxygen isotopes: First results of the Bourges cathedral (France). J. Geochem. Explor. 88(1-3) (2006) 358-362.

Weller, R., Woeltjen, J., Piel, C., Resenberg, R., Wagenbach, D., Koenig-Langlo, G., Kriews, M., Seasonal variability of crustal and marine trace elements in the aerosol at Neumayer station, Antarctica, Tellus B 60B(5) (2008) 742-752.

Xiao, H-W., Xiao, H-Y., Luo, L., Zhang, Z-Y., Huang, Q-W., Sun, Q-B., Zeng, Z-Q., Stable carbon and nitrogen isotope compositions of bulk aerosol samples over the South China Sea. Atmos. Environ. 193 (2018) 1-10. 
603 Yang, J., Wang, F., Influence of assumed absorption capacity of superabsorbent 604 polymers on the microstructure and performance of cement mortars, Construct. Build. Mater. 204 (2019) 468-478.

606

607

608

609

610

611

612

613

614

615

616

617

618

619

620

621

622

623

624

625

626

627

628

629

630

631

632

Zezza, F., Macrì, F., Marine aerosol and stone decay, Sci. Total Environ. 167(1-3) (1995) 123-143.

Zhang, Q-N., Zhang, Y., Cai, C., Guo, Y-C., Reid, J. P., Zhang, Y-H, In Situ Observation on the Dynamic Process of Evaporation and Crystallization of Sodium Nitrate Droplets on a ZnSe Substrate by FTIR-ATR, J. Phys. Chem. A $118(15)$ (2014) 2728-2737.

Zhou, X., Liu, D., Bu, H., Deng, L., Liu, H., Yuan, P., Du, P., Song, H., XRD-based quantitative analysis of clay minerals using reference intensity ratios, mineral intensity factors, Rietveld, and full pattern summation methods: a critical review. Solid Earth Sci. 3 (2018) 16-29.

\section{FIGURE CAPTIONS}

Figure 1. Location, type of material and sampling of the 23 samples from Villa Belza building (Biarritz, France).

Figure 2. XRD of building materials in Villa Belza of A) S4 (rendering mortar) with the presence of calcite $\left(\mathrm{CaCO}_{3}\right)$, quartz $\left(\mathrm{SiO}_{2}\right)$, halite $(\mathrm{NaCl})$ and portlandite $\left(\mathrm{Ca}(\mathrm{OH})_{2}\right)$ and B) S15 (joint mortar) with the presence of quartz $\left(\mathrm{SiO}_{2}\right)$, calcite $\left(\mathrm{CaCO}_{3}\right)$, ettringite $\left(\mathrm{Ca}_{6} \mathrm{Al}_{2}\left(\mathrm{SO}_{4}\right)_{3}(\mathrm{OH})_{12} .26 \mathrm{H}_{2} \mathrm{O}\right)$ and pyroaurite $\left(\mathrm{Mg}_{6} \mathrm{Fe}_{2}\left(\mathrm{CO}_{3}\right)(\mathrm{OH})_{16} \cdot 4 \mathrm{H}_{2} \mathrm{O}\right)$.

Figure 3. Raman spectra of S1, S2, S9, S10, S11, S12, S13, S14 and S20, indicating the presence of A) gypsum $\left(\mathrm{CaSO}_{4} \cdot 2 \mathrm{H}_{2} \mathrm{O}\right)$; B) basanite $\left(\mathrm{CaSO}_{4} \cdot 1 / 2 \mathrm{H}_{2} \mathrm{O}\right)$ and C) anhydrite $\left(\mathrm{CaSO}_{4}\right)$.

Figure 4. $\mu$-ED-XRF imaging of the S15 sample from Villa Belza (Biarritz, France) showing the elemental distribution maps of some of the detected elements. (For interpretation of the references to color in this figure, the reader is referred to the web version of this article.)

Figure 5. Bar charts showing cations and anions concentrations ( $\mathrm{mg} / \mathrm{kg}$ units) on each Villa Belza sample. 
633

634

635

636

637

638

639 
Table 1. Semi-quantitative information of mineralogical phases detected by XRD in the analyzed samples from Villa Belza (Biarritz, France).

\begin{tabular}{|c|c|c|c|c|c|c|c|c|c|c|c|c|}
\hline Samples & Type of Material & $\begin{array}{l}\text { Calcite } \\
\left(\mathrm{CaCO}_{3}\right)\end{array}$ & $\begin{array}{c}\text { Gypsum } \\
\left(\mathrm{CaSO}_{4} \cdot 2 \mathrm{H}_{2} \mathrm{O}\right)\end{array}$ & $\begin{array}{l}\text { Halite } \\
\text { (NaCl) }\end{array}$ & $\begin{array}{l}\text { Quartz } \\
\left(\mathrm{SiO}_{2}\right)\end{array}$ & $\begin{array}{c}\text { Mica } \\
\left(\mathrm{AC}_{2-3} \mathrm{~T}_{4} \mathrm{O}_{10} \mathrm{X}_{2}\right)\end{array}$ & $\begin{array}{c}\text { Dolomite } \\
\left(\mathrm{CaMg}\left(\mathrm{CO}_{3}\right)_{2}\right)\end{array}$ & $\begin{array}{l}\text { Microcline } \\
\left(\mathrm{KAISi}_{3} \mathrm{O}_{8}\right)\end{array}$ & $\begin{array}{c}\text { Kaolinite } \\
\left(\mathrm{Al}_{2} \mathrm{Si}_{2} \mathrm{O}_{5}(\mathrm{OH})_{4}\right)\end{array}$ & $\begin{array}{l}\text { Portlandite } \\
\left(\mathrm{Ca}(\mathrm{OH})_{2}\right)\end{array}$ & $\begin{array}{c}\text { Ettringite } \\
\mathrm{Ca}_{6} \mathrm{Al}_{2}\left(\mathrm{SO}_{4}\right)_{3}(\mathrm{OH})_{12} .26 \mathrm{H}_{2} \mathrm{O}\end{array}$ & $\begin{array}{c}\text { Pyroaurite } \\
\mathrm{Mg}_{6} \mathrm{Fe}_{2}\left(\mathrm{CO}_{3}\right)(\mathrm{OH})_{16} \cdot 4 \mathrm{H}_{2} \mathrm{O}\end{array}$ \\
\hline S1 & Limestone & $96 \%$ & $4 \%$ & $<1 \%$ & - & - & - & - & - & - & - & - \\
\hline S2 & Limestone & $93 \%$ & $3 \%$ & $1 \%$ & $3 \%$ & - & - & - & - & - & - & - \\
\hline S3 & Rendering mortar & $50 \%$ & - & $2 \%$ & $48 \%$ & - & - & - & - & - & - & - \\
\hline S4 & Rendering mortar & $41 \%$ & - & $2 \%$ & $54 \%$ & - & - & - & - & $2 \%$ & - & - \\
\hline S5 & Rendering mortar & $39 \%$ & - & $<1 \%$ & $61 \%$ & - & - & - & - & - & - & - \\
\hline S6 & Rendering mortar & $51 \%$ & - & $<1 \%$ & $49 \%$ & - & - & - & - & - & - & - \\
\hline S7 & Limestone & $92 \%$ & - & - & $8 \%$ & $<1 \%$ & - & - & $<1 \%$ & - & - & - \\
\hline S8 & Rendering mortar & $12 \%$ & - & - & $88 \%$ & - & - & - & - & - & - & - \\
\hline S9 & Sandstone & $55 \%$ & $2 \%$ & $1 \%$ & $34 \%$ & - & $8 \%$ & - & - & - & - & - \\
\hline S10 & Limestone & $96 \%$ & $4 \%$ & - & & - & - & - & - & - & - & - \\
\hline S11 & Limestone & $95 \%$ & $5 \%$ & - & & - & - & - & - & - & - & - \\
\hline S12 & Rendering mortar & $15 \%$ & $3 \%$ & - & $82 \%$ & - & - & - & - & - & - & - \\
\hline S13 & Sandstone & $2 \%$ & $2 \%$ & $1 \%$ & $95 \%$ & - & - & - & - & - & - & - \\
\hline S14 & Sandstone & $14 \%$ & $4 \%$ & - & $82 \%$ & - & - & - & - & - & - & - \\
\hline S15 & Joint mortar & $28 \%$ & - & - & $67 \%$ & - & - & - & - & - & $4 \%$ & $1 \%$ \\
\hline S16 & Sandstone & $15 \%$ & - & - & $75 \%$ & - & - & $10 \%$ & - & - & - & - \\
\hline S17 & Joint mortar & $28 \%$ & - & - & $70 \%$ & - & $2 \%$ & - & - & - & - & - \\
\hline S18 & Cement & $17 \%$ & - & $1 \%$ & $82 \%$ & - & - & - & - & - & - & - \\
\hline S19 & Rendering mortar & $16 \%$ & - & $<1 \%$ & $84 \%$ & - & - & - & - & - & - & - \\
\hline S20 & Sandstone & $12 \%$ & $7 \%$ & $1 \%$ & $80 \%$ & - & - & - & - & - & - & - \\
\hline S21 & Rendering mortar & $14 \%$ & - & $<1 \%$ & $86 \%$ & - & - & - & - & - & - & - \\
\hline S22 & Limestone & $75 \%$ & - & $<1 \%$ & $24 \%$ & - & - & - & - & - & - & - \\
\hline S23 & Rendering mortar & $49 \%$ & - & $2 \%$ & $49 \%$ & - & - & - & - & - & - & - \\
\hline
\end{tabular}




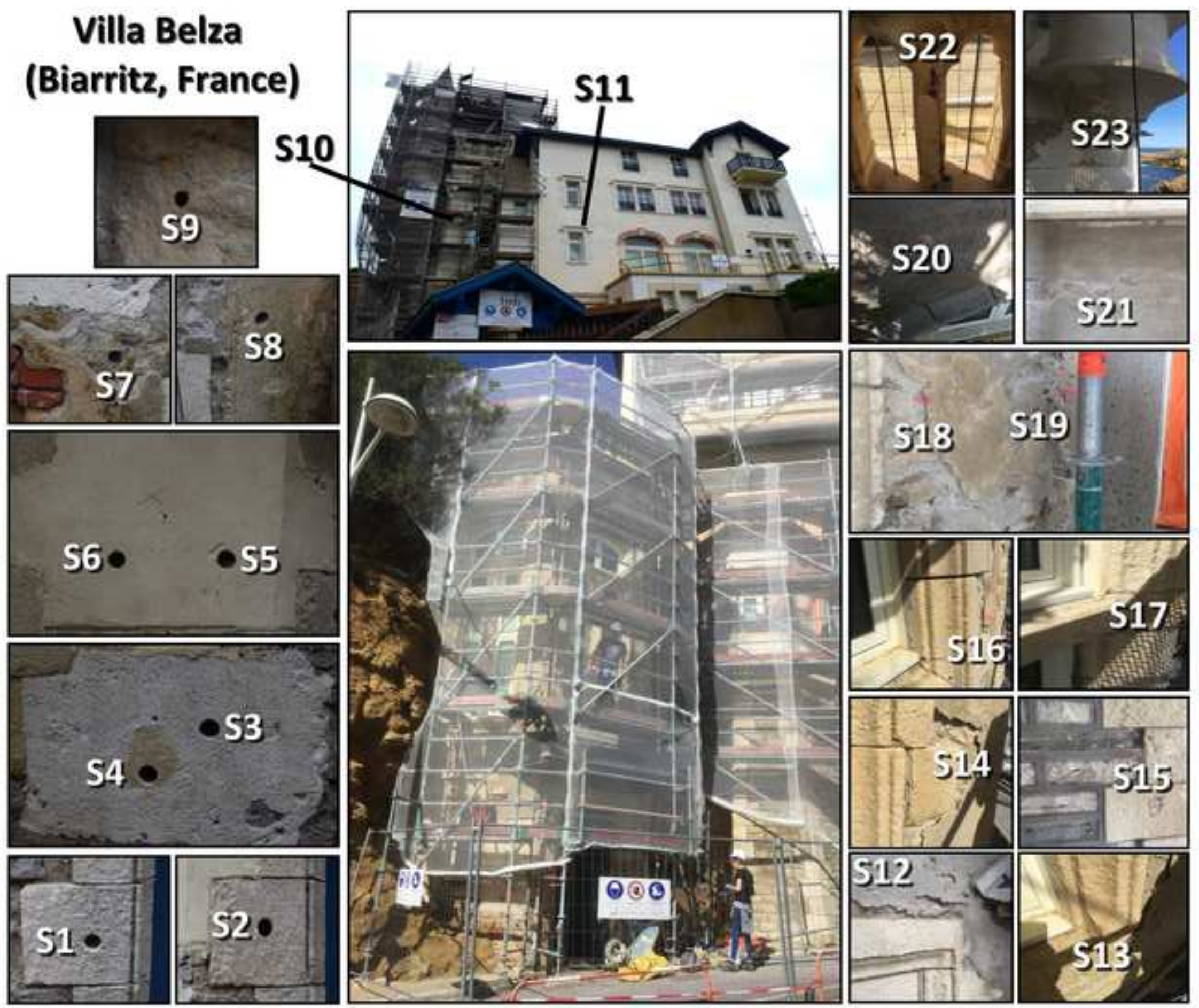

Figure 1 Villa Belza
(Biarritz, France)

$518 \quad 519$ 


\section{igure 2}

Click here to download high resolution image

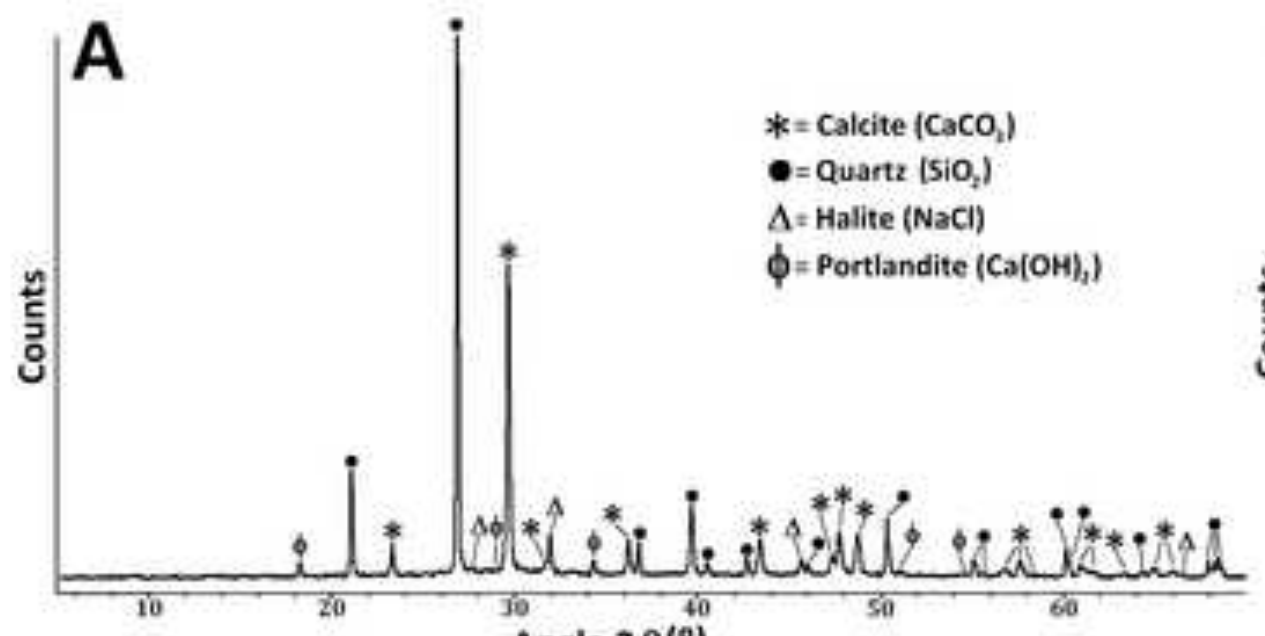
Angle $2 \theta\left(^{\circ}\right)$

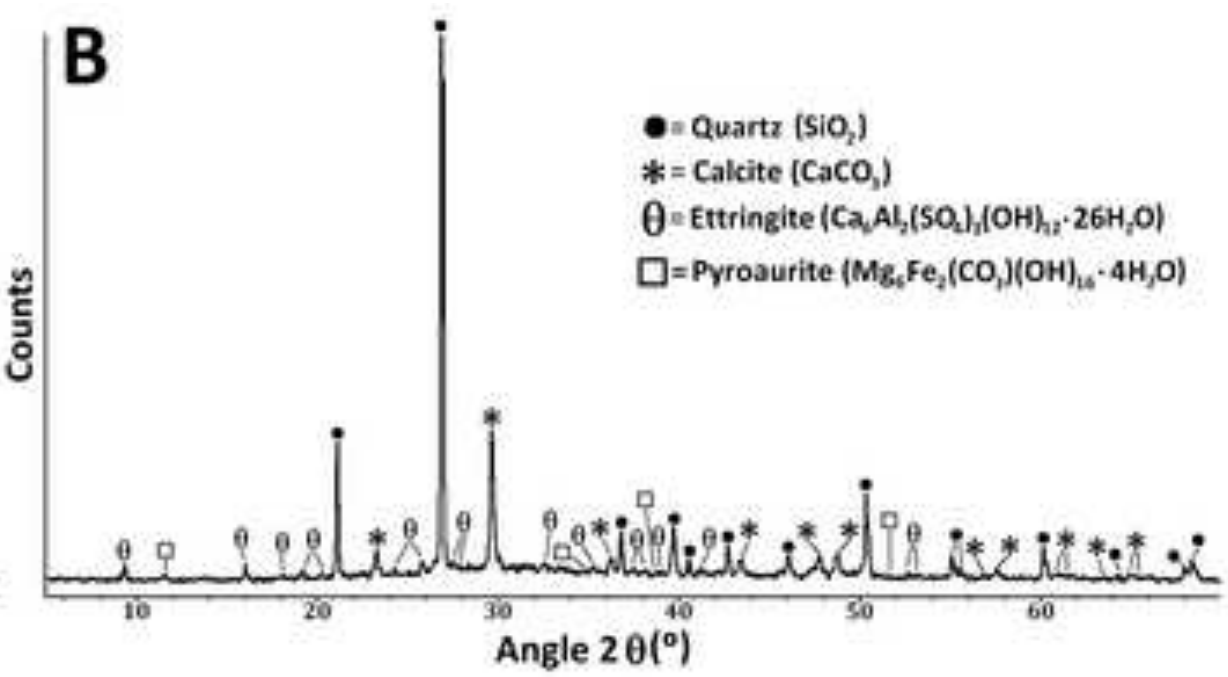



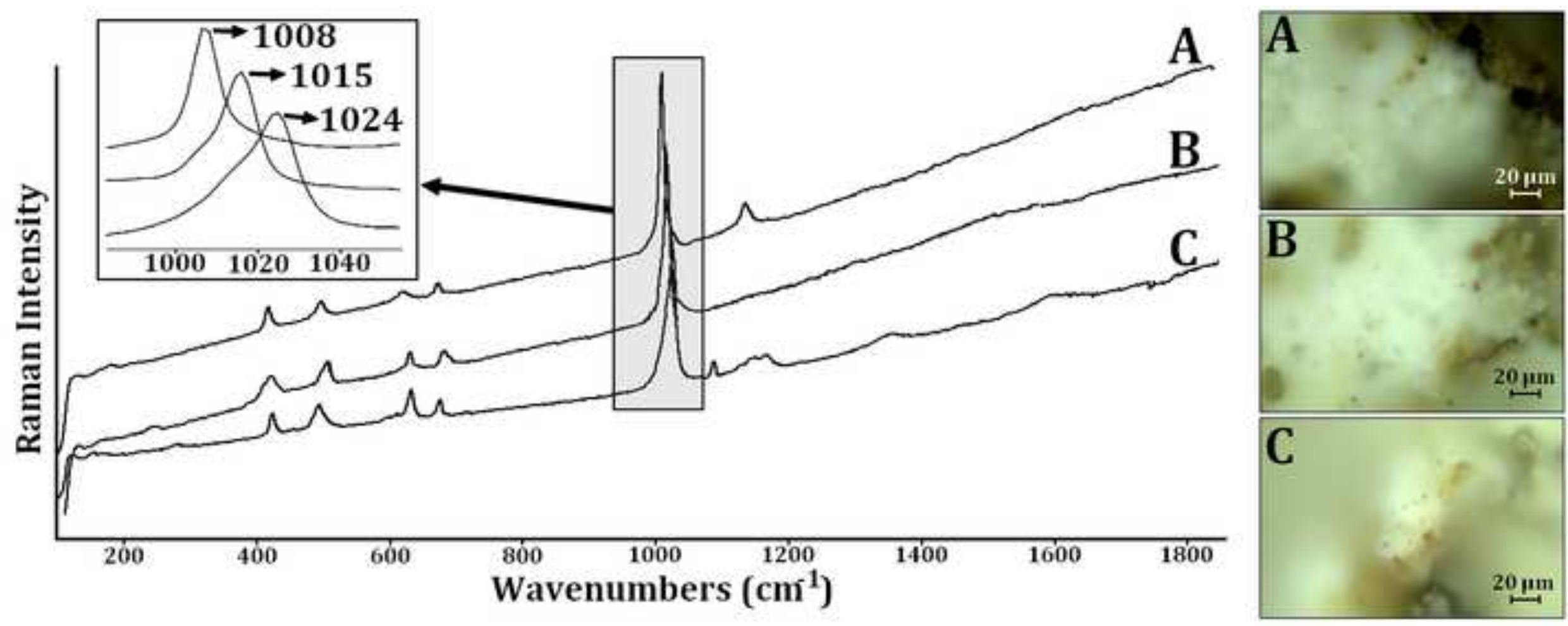
Click here to download high resolution image
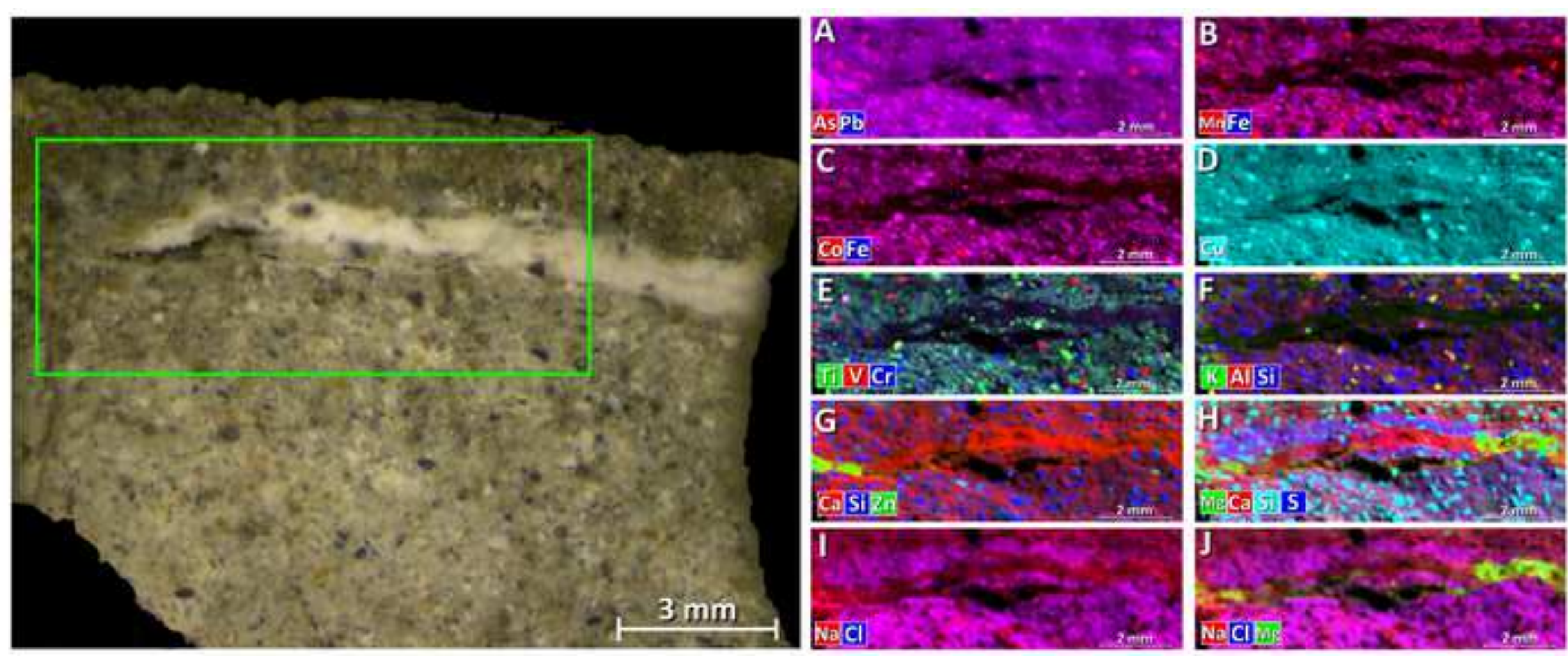

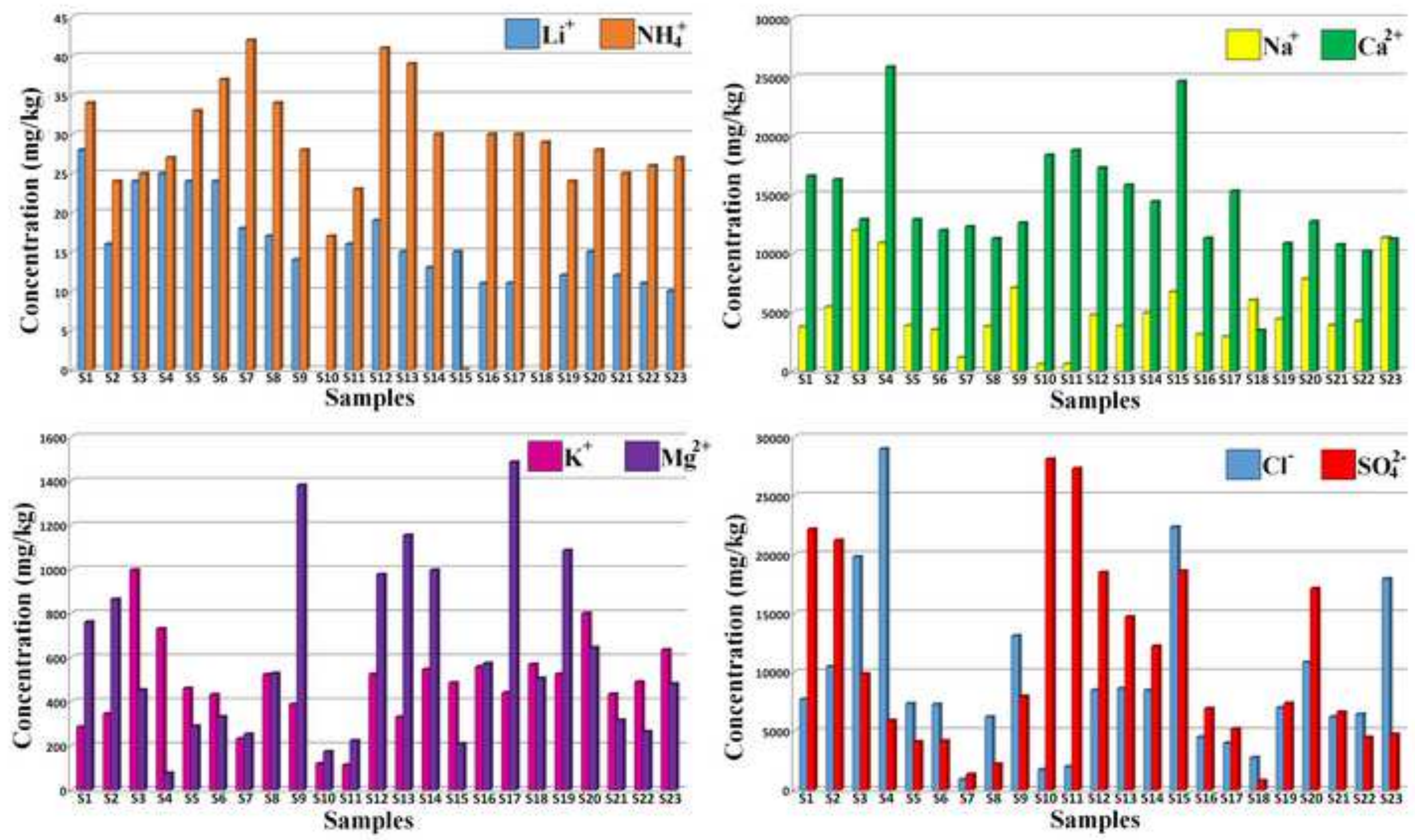